\title{
Preliminary development of the Vietnamese Marital Satisfaction Scale (MSS-VN): a pilot study using a Vietnamese intellectual sample
}

\begin{abstract}
BACKGROUND
The objective of the present study was to develop a scale to measure marital satisfaction within a Vietnamese context (Vietnamese Marital Satisfaction Scale - MSS-VN). Due to the lack of in-depth studies in Vietnam on marital satisfaction, as well as a paucity of specialized Vietnamese context measurement tools in this field, the marital satisfaction dimensions of the MSS-VN were based on extant research literature and the social-cultural context of Vietnamese intellectual couples.
\end{abstract}

\section{PARTICIPANTS AND PROCEDURE}

A group of 10 Vietnamese intellectuals (ages 28 to 43 years, five males/five females) were used to vet the MSS-VN questions during the question development phase of the study. The final version of the MSS-VN was administered to a convenience sample consisting of 144 male and 145 female Vietnamese intellectuals (age 22 to 50 years, $M=31.60, S D=5.40)$. Analysis involved tests of reliability and validity (internal consistency, content validity, and convergent validity).

\section{RESULTS}

The results in the exploratory factor analysis of the MSS-VN indicated the maintenance of 33 items, distributed in five factors: emotional support, division of responsibilities and housework, child-rearing, decision making and financial management, and cohesion. The convergent validity showed rather strong correlation between the final scale solution and the sub-scale "dyadic satisfaction" from the Dyadic Adjustment Scale of Spanier.

\section{CONCLUSIONS}

The MSS-VN was considered satisfactory for the proposed intent of developing a measure of marital satisfaction within a Vietnamese context, with consistency for application in other studies on Vietnamese intellectual's marital satisfaction; however, due to the limitation of the convenience sample, further evidence on the validation of the MSS-VN is required.

\section{KEY WORDS}

Vietnamese Marital Satisfaction Scale (MSS-VN); development; validation; intellectual

ORGANIZATION - 1: University of Social Sciences and Humanities - Vietnam National University, Hanoi, Vietnam .

2: Tianjin Normal University, Tianjin, China

AUthors' CONTRibutions - A: Study design - B: Data collection - C: Statistical analysis - D: Data interpretation .

E: Manuscript preparation · F: Literature search · G: Funds collection

Corresponding AUthor - Linh Thi Trinh, Ph.D., University of Social Sciences and Humanities (VNU-Hanoi), 336 Nguyen

Trai, Thanh Xuan, Hanoi, Vietnam, e-mail: anhlinh_huong@yahoo.com

to Cite this ARTICLE - Trinh, L. T., \& Phan, H. T. (2020). Preliminary development of the Vietnamese Marital Satisfaction

Scale (MSS-VN): a pilot study using a Vietnamese intellectual sample. Health Psychology Report, 8(1), 83-96.

https://doi.org/10.5114/hpr.2019.86701

RECEIVED 23.01.2019 • REVIEWED 03.05.2019 • ACCEPTED 03.06.2019 • PUBLISHED 16.07.2019 


\section{BACKGROUND}

Relationship satisfaction has become a central construct in foundational relationships research and marriage therapy literature. In the past 50-60 years, marital adjustment, happiness, and satisfaction have become popular research topics in the field of family studies (Burr, 1967; Hicks \& Platt, 1970; Nye, 1988; Spanier \& Lewis, 1980; Bradbury, Fincham, \& Beach, 2000; Johnson, Zabriskie, \& Hill, 2006; Jose \& Alfons, 2007; Jackson, Miller, Oka, \& Henry, 2014). This diverse research has led to the development of a number of widely used instruments measuring satisfaction and success in marriage. Early studies on marriage were characterized by a general examination of marriage using a unidimensional approach that assessed specific aspects or dimensions of interactions in marriage (Snyder, 1979). That is, some authors argued that "marital satisfaction" was a spouse's comprehensive view of married life, and this factor could be measured. This belief led researchers to develop the following assessment instruments: Marital Adjustment Test (Locke, 1951), Marital Satisfaction Index (Blood \& Wolfe, 1960), Marital Satisfaction Sentence Completions (Inselberg, 1961), Kansas Marital Satisfaction Scale (Schumm, Jurich, \& Bollman, 1981), Relationship Assessment Scale (Hendrick, 1988), and Couple Satisfactions Index (Fun \& Rogge, 2007). This unidimensional approach, however, was criticized by researchers who believed marriage was an extremely complex, diverse, and multidimensional relationship (Ward, Lundberg, Zabriskie, \& Berrett, 2009). For example, although individual members in a spousal relationship may be satisfied or dissatisfied with some aspects of marriage, it does not mean that they will be satisfied or dissatisfied about married life in general. Also, it is possible to falsely identify a non-distressed marriage as a satisfied marriage, when in reality the parties in the marriage do not have marital satisfaction (Ward et al., 2009). This multidimensional view of marital satisfaction led to the development of the Marital Satisfaction Indexes (Burr, 1970), Short Marital-Adjustment Test (Locke \& Wallace, 1959), Dyadic Adjustment Scale (Spanier, 1976), Marital Satisfaction Inventory (Snyder, 1983), Marriage and Relationship Questionnaire (Russel \& Wells, 1993), and Relationship Evaluation Questionnaire (Holman, Busby, Doxey, Klein, \& Loyer-Carlson, 1997). In this line of thinking, some researchers have argued that some aspects of married life (e.g., division of housework, financial management, child rearing) should be included in marital satisfaction assessment instruments (Bowerman, 1957; Burr, 1970; Manson \& Lerner, 1970; Honeycutt, 1986; Snyder, 1983; Russell \& Wells, 1993).

There is a paucity of research on marriage satisfaction in Vietnam and available research is limited in quantity and quality. That is, marital satisfaction is typically measured using a single Likert or ordinal scale question or embedded in a measure examining general satisfaction, quality of life, or quality of family life (Nguyen, 2015; Hoang, 2012). For example, Nguyen's 2016 study on the family life satisfaction of female victims of domestic violence examined the following aspects of family life: couple's emotional life, couple's problems solving, sex life, level of family care, recreational activities, husband's manner in treating his parents-in-law, family-friendly relationship, parentsin-law-daughters-in-law relationships, wife's work, family financial matter, family members' health conditions, children's learning, neighbors' relationships, and children's behavior. Do and Weiss's 2017 study on the satisfaction level of women in the first two years of marriage examined the family's emotional lives, financial decisions, sex life, housing task division, freedom in friend relationships, behavior of spouses with parentsin-law, etc. It appears these authors believe marriage satisfaction coincides with family life satisfaction in general. Although the overlap of marriage life and family life makes the comprehensive separation of these two concepts challenging, we believe that examining them as separate entities in research is necessary and beneficial. Furthermore, we view the family as a social institution and marriage as a social relationship; that is, marriage is the relationship between the couple. Therefore, we believe marital satisfaction must be defined for what it is (the relationship between the couple), and assessment of marriage satisfaction should only focus on the direct aspects of the relationship between husband and wife, not their role/function, or responsibilities related to the family. Although it is not often theoretically defined in the research, this present study defines marital satisfaction as an individual's subjective evaluation of all possible aspects of his or her married life.

Markus and Kitayama (1991) have noted, "people in different cultures have strikingly different constructs of self, of others, and of the interdependence of the two. These construals can influence, and in many cases determine, the very nature of individual experience, including cognition, emotion, and motivation" (p. 224). We concur with this statement and assert that it is vital that any instrument designed to measure marital satisfaction should also consider the socio-cultural-historical aspects of the couple. To this end, in developing the MSS-VN, we examined the published research findings in the field of marriage and family, and in the absence of existing measures in Vietnam, we assessed existing western marital satisfaction instruments. We also considered current trends in the life changes of Vietnamese intellectuals.

\section{WESTERN MARITAL SATISFACTION INSTRUMENTS}

The vast majority of marital satisfaction instruments, as well as research studies on marital satisfaction, 
have been developed in high-income Western countries (e.g., US, Europe), and it is uncertain to what extent previous findings are relevant in non-Western countries such as Vietnam. For example, Imamoglu and Yasak (1997) found different values for marital relationship in Turkish couples, and Wadsby (1998) found a different dimension of the Evaluation and Nurturing Relationship Issues, Communication and Happiness (ENRICH) scale among Swedish couples. Because the determinants of marital satisfaction are likely to be affected by socio-institutional backgrounds, we should be cautious regarding any generalization.

Several elements of Spanier's 1976 Dyadic Adjustment Scale (DAS) and Marital Satisfaction Inventory of Snyder (MSI; 1983), however, aligned with the theoretical underpinnings of the MSS-VN and were adapted for use in the MSS-VN. The DAS is a self-report instrument measuring marital satisfaction, which has been widely used in different cultures. It has four dimensions: 1) the level of consensus between husband and wife on important family issues (e.g., perceptions of life, entertainment, friends); 2) the level of general satisfaction with the marital relationship; 3) the level of relationship engagement (e.g., how often a problem is discussed by the couple, the extent to which they share, exchange ideas and views, the extent to which they participate in recreational activities); and 4) the consensus and satisfaction with emotional expression. The DAS has been adapted for several countries, and various abbreviated forms have been developed with adequate reliability and validity (Busby, Crane, Larson, \& Christensen, 1995; Hunsley, Best, Lefebvre, \& Vito, 2001; Santos-Iglesias, Vallejo-Medina, \& Sierra, 2009). In general, studies into the psychometric properties of the DAS report high total scale reliability. For example, in the meta-analysis performed by Graham, Liu, and Jeziorski (2006), the reliability of the global score was high, averaging .915 for the studies considered. Particularly, the dimensions of the DAS scale can be used separately without losing their reliability or validity (Graham et al., 2006; Spanier, 1976). The MSI of Snyder (1983) is a self-report measure that identifies, separately for each partner in a relationship, the nature and extent of distress along several key dimensions of their relationship (e.g., affective communication, problem-solving communication, leisure time together, disagreement about finances, role orientation, dissatisfaction with children, and conflict over childrearing). All of the MSI scales discriminated between nondistressed couples and couples in therapy (Snyder, 1979), as well as sex and marital therapy couples (Berg \& Snyder, 1983). Comparative reviews have identified the MSI as "the strongest marital satisfaction measure available in psychometric terms" (Fowers, 1990). The Marriage and Relationship Questionnaire (MARQ;
Russell \& Wells, 1993), is a general purpose 61-item inventory which can be administered to partners in a long-term relationship. The MARQ was originally designed to give a broad view of respondents' feelings both about themselves and about their relationship with their spouse. The scale includes 12 sub-scales assessing various aspects of marital relationships (e.g., roles, values, family ties, partnership, love, attractiveness, sexual jealousy, conciliation, problems). Although it is less well known, the MARQ is similar to many other measures of marital satisfaction to the extent that it has been used to benchmark associations between spousal perceptions and relationship satisfaction. It has also been considered as a valid instrument in many different cultures (Lucas et al., 2008).

\section{CURRENT TRENDS IN THE LIFE CHANGES OF VIETNAMESE INTELLECTUALS}

The statistics in Vietnam in recent years have shown that the role of females is becoming more and more important in the labor market. Females, especially female intellectuals, are stepping out of their homes to integrate and affirm their capacities in society (Tran \& Nguyen, 2015). This is followed by a change in roles, especially their roles in family life. We assume that this change is rather similar to the changes in married life of other couples in the world, especially in developing countries such as Vietnam. Thus, any discussion of marriage satisfaction of Vietnamese people must take into account the rapid economic and social developments in Vietnam society during the last few decades.

\section{PARTICIPANTS AND PROCEDURE}

The development of the MSS-VN consisted of two stages. Stage One was scale item development, and Stage Two was the MSS-VN administration pilot study.

\section{MSS-VN SCALE ITEM DEVELOPMENT}

The development of the scale items for the MSS-VN followed a two-part design: item construction and item refinement. Part one consisted of specifying domains of marital satisfaction and generating sample items. This was done by reviewing existent research literature and examining the Vietnamese social-cultural context. Following the guidelines of scale development procedures proposed by Churchill (1979), we first specified the dimension of marital satisfaction. This was accomplished by examining existing scales purporting to measure marriage satisfaction. Even
Preliminary development of the Vietnamese Marital Satisfaction Scale (MSS-VN) 
Linh Thi Trinh, Hanh Thi Phan though each examined scale has its own structure, there are similarities of some dimensions of the scales. Table 1 summarizes these dimension similarities.

Given that there are no existing standardized or norm-based marriage satisfaction assessment instruments in Vietnam and limited domestic research studies on marital satisfaction, we outlined the construct of marital satisfaction in Vietnamese intellectuals in the following aspects: emotional support, financial management, child rearing, housework division, decision making and cohesion. These dimensions were selected because of their repeated occurrence in quite a number of scales on this topic. Moreover, it also contains dimensions that three intellectuals in our network (one male, two female, ages 28 to 37 years) mentioned when they were asked about their aspects of marriage satisfaction.

Based on these dimensions, we generated items capturing these specific dimensions. The pilot questionnaire consisted of 50 items using a six-point Likert scale from 0 (always disagree) to 5 (always agree) to measure each specific aspect of marital satisfaction. Individual dimensions were as follows:

Marital cohesion. This dimension consisted of five items adapted from the Dyadic cohesion sub-scale of the DAS (Spanier, 1976). These five items (e.g., "you and your spouse have a stimulating exchange of ideas", "you work together on a project") were se-

Table 1

Dimension similarities between marital satisfaction scales

\begin{tabular}{|c|c|c|}
\hline Dimension & Scale (sub-scale) & $\begin{array}{l}\text { Authors } \\
\text { (year of publication) }\end{array}$ \\
\hline \multirow{4}{*}{$\begin{array}{l}\text { Emotional } \\
\text { support }\end{array}$} & Marital Need Satisfaction Scale (Love) & Stinnett et al. (1970) \\
\hline & Dyadic Adjustment Scale - DAS (Affectional express) & Spanier (1976) \\
\hline & Marital Satisfaction Inventory - MSI (Affective communication) & Snyder (1983) \\
\hline & Marriage and Relationship Questionnaire - MARQ (Love) & Russell and Wells (1993) \\
\hline \multirow{4}{*}{$\begin{array}{l}\text { Financial } \\
\text { management }\end{array}$} & Marital Satisfaction Indexes (Handling of finance) & Burr (1970) \\
\hline & $\begin{array}{l}\text { Enriching \& Nurturing Relationship Issues, Communication } \\
\text { \& Happiness (Financial management) }\end{array}$ & Olson et al. (1982) \\
\hline & $\begin{array}{l}\text { Marital Satisfaction Inventory - MSI (Disagreement about } \\
\text { finance) }\end{array}$ & Snyder (1983) \\
\hline & $\begin{array}{l}\text { Satisfaction with Marital Issues and Topics (Financial } \\
\text { management) }\end{array}$ & Honeycutt (1986) \\
\hline \multirow[t]{4}{*}{ Child-rearing } & Bowerman Marital Adjustment Scales (Child-rearing)) & Bowerman (1957) \\
\hline & Marriage Adjustment Scale (Children) & Mason and Lerner (1970) \\
\hline & $\begin{array}{l}\text { Enriching \& Nurturing Relationship Issues, Communication } \\
\& \text { Happiness (Children and marriage) }\end{array}$ & Olson et al. (1982) \\
\hline & $\begin{array}{l}\text { Marital Satisfaction Inventory - MSI (Conflict over } \\
\text { child-rearing) }\end{array}$ & Snyder (1983) \\
\hline \multirow[t]{4}{*}{$\begin{array}{l}\text { Housework } \\
\text { division }\end{array}$} & $\begin{array}{l}\text { Bowerman Marital Adjustment Scales (Homemaking } \\
\text { responsibilities) }\end{array}$ & Bowerman (1957) \\
\hline & Marital Satisfaction Indexes (Household tasks) & Burr (1970) \\
\hline & $\begin{array}{l}\text { Enriching \& Nurturing Relationship Issues, Communication } \\
\text { \& Happiness (Egalitarian roles) }\end{array}$ & Olson et al. (1982) \\
\hline & Marital Satisfaction Inventory - MSI (Role orientation) & Snyder (1983) \\
\hline \multirow{2}{*}{$\begin{array}{l}\text { Decision } \\
\text { making }\end{array}$} & Marital Need Satisfaction Scale (Respect) & Stinnett et al. (1970) \\
\hline & Dyadic Adjustment Scale - DAS (Consensus) & Spanier (1976) \\
\hline \multirow[t]{3}{*}{ Cohesion } & Dyadic Adjustment Scale - DAS (Cohesion) & Spanier (1976) \\
\hline & Short Marital-Adjustment Test (Cohesion) & Locke and Wallace (1959) \\
\hline & Marital Satisfaction Inventory - MSI (Time together) & Snyder (1983) \\
\hline
\end{tabular}


lected because we felt they were compatible with the married life of Vietnamese intellectuals. Accordingly, many Vietnamese intellectuals often talk together, plan together and work together to implement these plans in their life.

Decision making. This dimension consisted of ten items, two of which were adapted from the Dyadic consensus sub-scale of the DAS (Spanier, 1976). These two DAS items (e.g., "you agree with your spouse in making important decisions", and "you agree with your spouse in the decisions related to each person's career") were chosen because of their compatibility for married life of contemporary Vietnamese intellectual people, in which respect the relationship with each other is one of the most important things. The remaining eight items were developed to better understand the decision-making aspect of this married life related to what has often happened in Vietnamese traditional society (e.g., "in my family, the final decision is made by the husband", "in my family, the final decision is made by the wife", "you and your partner agree with each other on all decisions").

Financial management. This dimension consisted of eight items, five of which were adapted from the MSI (Snyder, 1983). These eight items were selected because they reflected the points that can be seen in any marriage life in terms of financial management. The other three items were added to more accurately reflect the financial management aspect of Vietnamese intellectual families today. This addition supports the perception of traditional Vietnamese society relative to the role of husbands and wives. That is, husbands are identified as a breadwinner and they manage all the big affairs of the family including the control of family income. Meanwhile, "in contemporary Vietnam, although men continue to be seen as primary breadwinners, women are expected to make economic contributions to the household" (Dalton, Pham, Pham, \& Ong, 2002). The three items were: "your spouse usually does not disclose household expenses", "you and your spouse manage your own personal income", and "in the family all earnings are kept by one (husband or wife)".

Emotional support. This dimension consisted of nine items, five adapted from the MARQ of Russell and Wells (1993), and two of which were adapted from the "affectional expression" sub-scale of the DAS of Spanier. The last two items were adapted from the MSI of Snyder. These items were chosen because of their generalization in reflecting the emotional support aspect of married life that can be seen in any culture (e.g., "your spouse does a lot to show that he/she loves you very much", "your spouse assists you in what you are trying to do").

Child-rearing. This dimension consisted of nine items, in which four items adapted from the MSI of Snyder, and other four items were adapted from the MARQ of Russell and Wells. As we explained above, these items were selected because they captured Vietnamese intellectuals' culture. One additional item (i.e., "having a child is the consensus of both you and your spouse") was added so as to adapt to the Vietnamese culture of child-rearing. That is, in the traditional Vietnamese culture, the perception of women is that they are considered to be a "spawning machine", meaning that women do not have the right to decide whether or not to have children. In traditional Vietnamese culture, it is the husband's right to make decisions regarding pregnancy. Therefore, recognition of the role of women in this domain is necessary when understanding about the marital satisfaction of intellectuals in contemporary Vietnam.

Housework division. This dimension consisted of nine items, including four items adapted from the MSI of Snyder (e.g., "your spouse and you equally share your household tasks", "unequal division of housework is contributing to your unhappy marriage"). These adaptations were due to their compatibility with the married life of Vietnamese intellectuals. The remaining five items were constructed based on the real life of married Vietnamese intellectual couples.

The completed six-dimension MSS-VN has a theoretical range of $0-250$, with a high score representing a person with a high level of marital satisfaction.

The drafted questionnaire was administered to 10 Vietnamese intellectuals (ages 28 to 43 years, five females, five males) in order to test the suitability and comprehensibility of the items. These subjects were selected using a convenience sampling method. They represented a sample from a diverse range of common occupations who graduated from a university or college and they were currently working in Hanoi. In addition to completing the Likert items, participants were asked to comment about the appropriateness of the given dimensions compared to their actual life. The results of the survey indicated that in general, items were considered to be easy to understand, and the given dimensions were in line with participants' reality. As a result of participant feedback, five statements were refined in accordance with participant suggestions. The aspect of sexual life in relation to marital satisfaction was questioned by one of these 10 intellectuals regarding appropriateness. In recognition of this concern, an investigation of research literature on the subject of marital sexual satisfaction was also carried out. The result of this literature review revealed that sexual satisfaction has been often regarded as not only a component, but also a factor affecting marriage satisfaction (Volsky, 1998; Barrientos \& Páez, 2006; Davison, Bell, LaChina, Holden, \& Davis, 2009). As a result, given the framework of this study, the decision was made to retain the dimension. Furthermore, based on participant feedback all six dimensions of marital satisfaction set out in the assessment were retained.
Preliminary development of the Vietnamese Marital Satisfaction Scale (MSS-VN) 


\section{ENGLISH ADAPTION}

Items from English version tests that were used in the MSS-VN were independently translated into Vietnamese. Two translators were used. They were Vietnamese faculty members who teach English at a university in Vietnam. To guarantee that all the items were accurately translated into Vietnamese, the translations were back-translated into English by a Vietnamese student fluent in English who is currently living and studying at a university in Australia. The two translated versions were then compared to guarantee the closest translation of the terms. The final Vietnamese version of these items was checked and reviewed by our research team and by Vietnamese colleagues working in the area of psychology.

\section{MSS-VN ADMINISTRATION PILOT STUDY}

Following item development and refinement, a pilot study was conducted in order to obtain initial reliability and validity data on the MSS-VN.

\section{SAMPLE SELECTION AND DEMOGRAPHICS}

In the framework of an explorative study with limitation of time and budget, participants were recruited through convenience sampling methods. Potential participants had to be 18 years of age, or older, and currently in a couple relationship. Once identified, potential participants were sent a copy of the ques-

Table 2

Demographic characteristics of participants

\begin{tabular}{llc}
\hline & & Percent \\
\hline \multirow{2}{*}{ Gender } & Male & 49.83 \\
& Female & 50.17 \\
Age & College & 23.53 \\
& Pniversity & 54.67 \\
& 22-30 & 21.80 \\
& $31-40$ & 44.30 \\
Living with & Husband's parents & 49.80 \\
& Wife's parents & 5.90 \\
& No husband's or wife's & 3.80 \\
& parents & 51.20 \\
& Other & 1.10 \\
\hline
\end{tabular}

tionnaire and a letter inviting participation. The letter explained the purpose of the study (i.e., to help improve the empirical research in this field in Vietnam) and encouraged both members of the couple to join in the survey. Participants were also informed that it would take 25-30 minutes to complete the survey. The letter indicated that spouses were to complete the questionnaire independently and return it directly to the researcher. Participants were informed that information obtained would be kept confidential and that participant anonymity was guaranteed.

The sample included 164 couples $(N=328)$ living in Hanoi, Vietnam. There were 39 couples, in which only one of the dyad (husband or wife) completed the questionnaire. Thus, the total subjects were 145 women and 144 men $(N=289)$. The mean age of the sample was 31.60 years old $(S D=5.40)$. The demographic characteristics of participants are shown in Table 2.

\section{RESULTS}

Statistical calculations were performed using IBM SPSS Statistics version 22.0. All the statistical methods in this research were supported by SPSS and the total negative items were reversed before entering the analyses.

\section{EXAMINING MSS-VN PROPERTIES USING CRONBACH'S A COEFFICIENT AND EXPLORATORY FACTOR ANALYSIS}

To identify the major marital satisfaction dimensions of the population, we conducted a principal component factor analysis and extracted five factors that were evident on the scree plot that had an eigenvalue greater than one. Next, we eliminated items that did not strongly influence any factor (values below .45) or had cross-loadings (Stevens, 2002, cited by Field, 2009). A total of 17 items were therefore deleted after six iterations. The remaining 33 items were again factor analyzed. Each item was found to load strongly on only one factor. Five generated factors (Table 3) account for $53.23 \%$ of the variance, satisfying the requirement for mathematical statistics for factor analysis to be performed (Field, 2009). In other terms, EFA indicated adequate psychometric results for the instrument.

The extracted factors: 1) emotional support, 2) division of responsibility and housework, 3) child-rearing, 4) decision making and financial management, and 5) cohesion maintained 33 original items of the scale, taking into account the criterion of reliability in their factor loading.

Data analysis shows that $\mathrm{KMO}=0.87$, which is rather positive and meets the criteria of $0.5 \leq \mathrm{KMO} \leq 1$ 
Table 3

Summary of exploratory factor analysis results of the MSS-VN

\begin{tabular}{lc}
\hline Items & R \\
\cline { 2 - 2 } & 1 \\
\hline Your spouse takes care of you. & .7 \\
Your spouse is sympathetic to you when you are under pressure. & .7 \\
Your spouse understands you. & .78 \\
Your spouse assists you in what you are trying to do. & .75 \\
Your spouse does a lot to show that he/she loves you very much. \\
You feel the love that your spouse gives to you. \\
You trust the way your partner looks after your family. \\
You feel secure because your spouse loves and takes care of your children. \\
You are satisfied about how your spouse supports you in your family's \\
daily work.
\end{tabular}

You find it unfair to you in the division of housework.

Your spouse is responsible for purchasing household items.

Your spouse usually makes decisions on the housework without consulting you.

You think your spouse must spend more time with you.

In your family, you do almost all the housework.

In your family, you do not have to pay much attention to the housework.

In your family, the last decision maker must be the husband.

You and your spouse always agree on how to teach your child.

Your spouse often talks to you very carefully before making decisions regarding the children.

Your spouse is a good parent.

Your spouse respects you in making decisions related to your children.

Children make your marital relationship better.

Having a child is the consensus of both you and your spouse.

You agree with your spouse in making important decisions.

You agree with your spouse in the decisions related to each person's career.

You even have a fierce debate about the decision your spouse makes.

You and your spouse always agree on the expenses of the family.

You and your spouse manage your own income.

In your family, all income is attributable to one (husband or wife).

You trust your partner's decisions.

You and your spouse have a stimulating exchange of ideas.

You laugh together.

You work together on a project. 
Linh Thi Trinh, Hanh Thi Phan
(Hutcheson \& Sofroniou, 1999, cited by Field, 2009). Bartlett's test of sphericity $\chi^{2}(1830)=7645.55, p<.001$, indicated that correlations between items were sufficiently large for PCA.

To assay the reliability of the instrument, we employed Cronbach's $\alpha$ for each dimension of PCA factor and for the whole scale. Table 4 summarizes the reliability coefficients for the total scale and its components. They were: $.81, .78, .79, .79, .77$, and .83, respectively. Thus, the reliability of the scales was deemed acceptable (Field, 2009).

To test the content validity of the scale, items included in the MSS-VN were independently evaluated by two judges from the field of psychology. Items were retained only if the judges considered the items to be: 1) relevant measures of marital satisfaction for contemporary intellectual spouses in Hanoi, Vietnam; 2) consistent with the dimension; and 3) care-

Table 4

Reliability for the MSS-VN and its component subscales

\begin{tabular}{lcc}
\hline & $\begin{array}{r}\text { Number } \\
\text { of items }\end{array}$ & $\begin{array}{c}\text { Cronbach } \\
\alpha\end{array}$ \\
\hline $\begin{array}{l}\text { 1. Emotional support } \\
\text { 2. Division of responsibility } \\
\text { and housework }\end{array}$ & 9 & .78 \\
$\begin{array}{l}\text { 3. Child-rearing } \\
\text { 4. Decision making and } \\
\quad \text { financial management }\end{array}$ & 7 & .79 \\
$\begin{array}{l}\text { 5. Cohesion } \\
\quad \text { General satisfaction }\end{array}$ & 4 & .77 \\
\hline
\end{tabular}

Note. Cronbach's coefficient alpha is used as the reliability estimate. fully worded with appropriate fixed choice responses. All 33 items were found to meet the criteria.

At present, as mentioned, research on marital satisfaction in Vietnam is still minimal in quantity and quality. Most available research studies considered marital satisfaction as an aspect of life satisfaction. Additionally, there is a lack of specialized studies on the topic of marital satisfaction in Vietnam, especially within the intellectual population. Given this context, to examine the convergent validity of the scale, we conducted a Pearson correlation analysis between the MSS-VN and Spanier's (1976) 10-item "dyadic satisfaction" sub-scale, which has been used widely (Bradbury et al., 2000). As can be seen from Table 5, the results indicate that the two scales have a strong positive correlation $(r=.62, p<.001)$. Hence, the scale meets statistical criteria for possessing adequate reliability and validity.

\section{MARITAL SATISFACTION IN TERM OF MEAN SCORES AND STANDARD DEVIATIONS}

Table 6 shows that in general, intellectual couples were moderately satisfied with their married life $\left(\Sigma_{\text {(total) }}=115.50, S D_{\text {(total) }}=18.90\right)$. The dimension of childrearing had the highest score $(\Sigma=23.87, S D=4.41)$ in comparison with the other four dimensions of the scale. Stated differently, overall the participants in this study indicated they were moderately satisfied with their marital life. In addition, child-rearing satisfaction and emotional support appeared to be the top two indicators of marital satisfaction. In contrast, intellectual couples were found to be less satisfied with the division of responsibilities and housework in comparison to the rest of the marital satisfaction's dimensions $(\Sigma=22.31, S D=6.38)$.

Table 5

Correlations between the MSS-VN and the Dyadic Satisfaction Sub-Scale of Spanier (1976)

\begin{tabular}{|c|c|c|c|c|c|c|c|}
\hline Variables & 1 & 2 & 3 & 4 & 5 & 6 & 7 \\
\hline 1. Emotional support & - & & & & & & \\
\hline 2. Child-rearing & $.41^{* *}$ & - & & & & & \\
\hline $\begin{array}{l}\text { 3. Decision making and finan- } \\
\text { cial management }\end{array}$ & $.45^{* *}$ & $.43^{* *}$ & - & & & & \\
\hline 4. Cohesion & $.24^{* *}$ & $.24^{* *}$ & $.37^{* *}$ & - & & & \\
\hline $\begin{array}{l}\text { 5. Division of responsibility and } \\
\text { housework }\end{array}$ & $.47^{* *}$ & $.38^{* *}$ & $.37^{* *}$ & $.21^{* *}$ & - & & \\
\hline $\begin{array}{l}\text { 6. General marital satisfaction } \\
\text { (total scale) }\end{array}$ & $.78^{* *}$ & $.67^{* *}$ & $.74^{* *}$ & $.53^{* *}$ & $.74^{* *}$ & - & \\
\hline $\begin{array}{l}\text { 7. Spanier's Dyadic satisfaction } \\
\text { sub-scale }\end{array}$ & $.39^{* *}$ & $.52^{* *}$ & $.52^{* *}$ & $.43^{* *}$ & $.34^{* *}$ & $.62^{* *}$ & - \\
\hline
\end{tabular}

Note. ${ }^{* *}$ Correlation is significant at the .01 level (2-tailed). 
Table 6

Summary scores and standard deviations for MSS-VN and its subscales

\begin{tabular}{lrrrrrr}
\hline & \multicolumn{2}{c}{ Male } & \multicolumn{2}{c}{ Female } & \multicolumn{2}{c}{ Total } \\
\cline { 2 - 7 } & \multicolumn{1}{c}{$\Sigma$} & $S D$ & $\Sigma$ & \multicolumn{1}{c}{$S D$} & \multicolumn{1}{c}{$\Sigma$} & $S D$ \\
\hline Emotional support & $\mathbf{3 2 . 2 8}$ & 6.55 & 31.62 & 6.76 & $\mathbf{3 1 . 9 5}$ & 6.65 \\
Division of responsibility and housework & 22.20 & 6.20 & 22.43 & 6.58 & $\mathbf{2 2 . 3 1}$ & 6.38 \\
Child-rearing & 23.72 & 4.41 & 24.01 & 4.43 & $\mathbf{2 3 . 8 7}$ & 4.41 \\
Decision making and financial management & 24.35 & 4.95 & 24.54 & 5.20 & 24.45 & 5.08 \\
Cohesion & 12.88 & 4.30 & 13.01 & 4.09 & 12.94 & 4.19 \\
General satisfaction & 115.42 & 18.42 & 115.58 & 19.43 & 115.50 & 18.90 \\
& \multicolumn{2}{c}{$N=144$} & & $N=145$ & & $N=289$ \\
\hline
\end{tabular}

Preliminary development of the Vietnamese Marital Satisfaction Scale (MSS-VN)

Table 7

Differences between males and females in terms of satisfaction with married life

\begin{tabular}{|c|c|c|c|c|c|c|c|c|c|}
\hline & \multicolumn{2}{|c|}{ Levene's test } & \multicolumn{7}{|c|}{$t$-test } \\
\hline & \multirow[t]{2}{*}{$F$} & \multirow[t]{2}{*}{$p$} & \multirow[t]{2}{*}{$t$} & \multirow[t]{2}{*}{$d f$} & \multirow[t]{2}{*}{$p$} & \multirow[t]{2}{*}{$\begin{array}{c}\text { Mean } \\
\text { difference }\end{array}$} & \multirow[t]{2}{*}{$\begin{array}{l}\text { Std. error } \\
\text { difference }\end{array}$} & \multicolumn{2}{|c|}{$\begin{array}{c}95 \% \text { confidence } \\
\text { interval }\end{array}$} \\
\hline & & & & & & & & Lower & Upper \\
\hline $\begin{array}{l}\text { Emotional } \\
\text { support }\end{array}$ & .11 & .741 & .84 & 280 & .400 & .67 & 0.79 & -0.89 & 2.25 \\
\hline $\begin{array}{l}\text { Division of } \\
\text { responsibility } \\
\text { and housework }\end{array}$ & .00 & .969 & -.55 & 282 & .579 & -.29 & 0.52 & -1.32 & 0.74 \\
\hline Child-rearing & .04 & .842 & -.31 & 286 & .754 & -.19 & 0.60 & -1.36 & 0.99 \\
\hline $\begin{array}{l}\text { Decision making } \\
\text { and financial } \\
\text { management }\end{array}$ & .41 & .523 & -.25 & 285 & .802 & -.13 & 0.49 & -1.10 & 0.85 \\
\hline Cohesion & .91 & .339 & -.31 & 284 & .758 & -.23 & 0.76 & -1.72 & 1.25 \\
\hline $\begin{array}{l}\text { General } \\
\text { satisfaction }\end{array}$ & .68 & .410 & -.07 & 274 & .937 & -.16 & 2.28 & -4.65 & 4.33 \\
\hline
\end{tabular}

\section{MARITAL SATISFACTION BY GENDER}

Though Table 7 depicts no statistically significant differences between males and females regarding marital satisfaction in general, as well as in certain aspects, Table 6 indicates that there was a slight difference between these two groups in regard to emotional support. Accordingly, male intellectuals' satisfaction with emotional support was slightly higher than that in females, with a mean of 32.28 and 31.95 , respectively. This finding, while not statistically significant, is consistent with the majority of the results obtained in the field of marital satisfaction (Vaughn \& Baier, 1999; Turliuc \& Muraru, 2013). Further research needs to be conducted with this population to explore this finding.

\section{MARITAL SATISFACTION OF INTELLECTUALS BY AGE}

Considering satisfaction with married life of intellectuals by age, the results did not indicate any statistically significant differences between age groups in almost every aspect, except for satisfaction with child-rearing. As indicated in Table 8, satisfaction in the aspect of child-rearing of intellectuals was higher in older groups. Specifically, while the intellectuals of the age group of 22 to 30 are still facing difficulties in becoming a good parent in the eyes of their spouse and making decisions regarding children, those belong to the age group of 41-60 seemed to have found common ground in this aspect. 
Table 8

Satisfaction with child-rearing of intellectuals by age

\begin{tabular}{cccccc}
\hline Age group & $\begin{array}{c}\text { Satisfaction } \\
\text { with children }\end{array}$ & $d f$ & $F$ & $p$ \\
\hline $22-30$ & $\Sigma$ & $\mathbf{2 3 . 2 1}$ & & \\
& $N$ & 118 & & \\
& $S D$ & 4.29 & & \\
$31-40$ & $\Sigma$ & $\mathbf{2 4 . 3 5}$ & & & \\
& $N$ & 134 & & & \\
& $S D$ & 4.30 & & & \\
$41-60$ & $\Sigma$ & $\mathbf{2 6 . 5 6}$ & & & \\
& $N$ & 16 & & & \\
& $N$ & 5.15 & & \\
Total & $S D$ & 23.98 & & \\
& $N$ & 268 & & \\
& $S D$ & 4.42 & & \\
\hline
\end{tabular}

\section{DISCUSSION AND CONCLUSION}

\section{MARITAL SATISFACTION OF INTELLECTUALS IN VIETNAM}

Although many studies have found that in general, wives' reports of marital satisfaction are significantly lower than husbands' (Myers \& Booth, 1999; Amato, Booth, Johnson, \& Rogers, 2007; Whiteman, McHale, \& Crouter, 2007), the results of our research suggest another nuance in a sample of intellectuals in Hanoi, Vietnam. Although there was a slight, nonsignificant difference in the mean score levels of husbands' and wives' marital satisfaction, which we will discuss more deeply below, the findings of the present research found no significant gender differences. However, based on the literature review, we recognize that this result is not new in the field of marriage and family. For example, Jackson et al. (2014) pointed out that the gender differences in marital satisfaction are due to the inclusion of clinical samples, with wives in marital therapy $51 \%$ less likely to be satisfied with their marital relationship. Meanwhile, for nonclinical populations, this difference is not underlined. This tendency is also observed in research of Broman (2005), Kurdek (2005), as well as Gager and Sanchez (2003). In addition, we recognize that respondents of the present research were intellectuals and that quality and respect for each other tend to be emphasized in this group.

In terms of dimensions of marital satisfaction, several studies argue that having children is a factor reducing the quality of married life, especially in the situation of young couples (Belsky \& Rovine, 1990; Waite \& Lillard, 1991). However, our study showed a different nuance in a Vietnamese sample of intellectuals. In our study, intellectuals report that their spouses were good parents. In addition, they were aligned in their decision-making and parenting of their children, and appear to realize that children help make their marital relationship better. Bradbury and his colleagues (2000) found that it was easy for couples in Eastern cultures to receive support from their family or relatives while having children. Therefore, the pressure placed on couples is often reduced. In other words, a couples' relationship will not be affected by their children's presence (Pasch \& Bradbury, 1998; Bradbury et al., 2000). However, in Vietnamese culture, getting married and then having children is not only the concern of the couple, but the whole family and clan as well. Therefore, it is easy to understand that in Vietnam, the presence of children facilitates the couple's relationship. This finding is consistent with Hoang's 2012 research on Vietnamese's general life satisfaction. Accordingly, people in the present intellectual sample reported that they were most satisfied in the field of parent-child relationship.

Regarding the emotional support dimension, we interpret the results of this domain in the current study as a positive sign for Vietnamese couples. As Caughlin (2002) observed, the more a husband and wife are close to, and open with, each other, the better the relationship - which is the core of a successful marriage. Studies in the field of marriage and family also showed that negative and avoidable communication behaviors are the primary cause of marriage failure and vice versa (Christensen \& Shenk, 1991; MacEwen \& Barling, 1993; Lavner, Karney, \& Bradbury, 2016). In our study, the results suggest that support and sharing between the intellectual couple in emotional life is positive and there are no conflicts or avoidance. This is reflected in the high positive consensus with several items, such as "your spouse takes care of you"; "you feel the love that your spouse gives to you"; "your spouse does a lot to show that he/she loves you very much".

Despite the entry of women into the labor market in Vietnam, the division of housework seems not to have changed much from the past. Yogev (1981, cited by Huppé \& Cyr, 1997) asserted that the traditional family model with the perspective of females being housewives was a popular pattern in society. The work of Benin and Agostinelli (1988) indicated that females spent twice as much time each week on housework as males. Even though some studies confirmed that there has been a change in the division of housework between husband and wife (Li, Zhang, Sin, \& Zhao, 2006; Pimentel, 2006), the change remains negligible. In Vietnam, the results of a research study on gender role and quantifying labor value in family (Vo, 2007) suggested that "the amount of time 
females spend on housework decreases in correlation with the increase of their education level". However, according to a survey conducted on civil servants at the Vietnam Academy of Social Sciences (2008), "on average, females spend more than one hour and a half per day on housework compared to males..." (cited by Le, 2015, p. 297). Thus, while only $9.70 \%$ of male intellectuals in our study indicated that the division of housework with their spouses did not meet their expectations, that rate for female intellectuals was $13.30 \%$. Nonetheless, this difference is not statistically significant when we examine the household division as a dimension of marital satisfaction. Is it possible, however, that women participants have involved the gender stereotypes of traditional Vietnamese society in which they assume that housework is the responsibility of women, and as a result, when they receive housework sharing from their husbands (albeit very little and as a symbolic act) they feel satisfied without demanding anything more. Further research is needed to explore this possibility.

\section{THE FIVE-FACTOR MSS-VN}

There were five dimensions of marital satisfaction perceived by the intellectuals in Hanoi, Vietnam who participated in this study. These were consistent with our initial dimensions, except for the mergence of the two factors "decision making" and "financial management". Initially, these were viewed as two distinct dimensions. However, our results indicated that they were connected; consequently, they were merged into one factor acknowledged as "decision making and financial management”. One primary reason might be explained by the socio-cultural context of Vietnamese intellectual couples. That is, in traditional Vietnamese society, the decision-making and financial management in the family is the responsibility of the husband, who is also the breadwinner. Although the current intellectual Vietnamese society has progressed in several aspects, in comparison with those before, the concept of the head of the family has changed slowly; most people still consider men as family owners. They are often the "owner" of valuable assets and tend to be the ones making important domestic decisions (Nguyen, 2012). In other words, these two facets are parallel, yet they are intertwined and closely related. Consequently, those dimensions were not recognized separately by the participants in the scope of this study.

Although marital satisfaction has been a topic of concern for many decades, it is still a new one in Vietnam. As one of the first in-depth psychological studies on this topic, we expect that this research will open new approaches for researchers in this field, particularly in adaptation and development of instruments assessing marital satisfaction. Regarding this study, although the MSS-VN initially satisfies statistical criteria, it is necessary to survey a larger and more diverse population.

\section{LIMITATION OF THE CURRENT STUDY}

The results presented in this paper are based on the responses of married adults from a convenience sample. Convenience sampling is a non-probabilistic technique where participants are selected because of their convenient accessibility and proximity to the researcher. Thus, this type of sample may not be representative of Vietnamese couples, intellectual or otherwise. Moreover, the current sample consisted of residents in Vietnam's capital city with education levels at a tertiary level - Bachelor's degree or higher. These demographic variables may influence how individuals perceive and interpret various aspects of a marital relationship. Therefore, the suitability and comprehensibility of the MSS-VN items should be tested with analysis of measurement invariance in future studies. As a result, it is still necessary to carefully consider the generalization of our five-dimension scale, and the results from the current study should be interpreted with caution.

\section{ACKNOWLEDGMENT}

The authors would like to thank the reviewers for all of their careful, constructive and insightful comments in relation to this work. Special thanks to Associate Professor Paul B. Jantz from Texas State University for his suggestive ideas and his time spent proofreading this manuscript.

The first author gratefully acknowledges a research grant from the Vietnam National University (VNU-Hanoi) (QG.16.47).

\section{REFERENCES}

Amato, P. R., Booth, A., Johnson, D. R., \& Rogers, S. J. (2007). Alone together: How marriage in America is changing. Cambridge, MA: Harvard University Press.

Barrientos, J. E., \& Páez, D. (2006). Psychosocial variables of sexual satisfaction in Chile. Journal of Sex \& Marital Therapy, 32, 351-368. https://doi. org/10.1080/00926230600834695.

Belsky, J., \& Rovine, M. (1990). Patterns of marital change across the transition to parenthood: Pregnancy to three years postpartum. Journal of Marriage and the Family, 52, 5-19. https://doi.org/10.2307/352833

Benin, M. H., \& Agostinelli, J. (1988). Husbands' and wives' satisfaction with the division of labor. Journal of Marriage and the Family, 50, 349-361. http:// dx.doi.org/10.2307/352002
Preliminary development of the Vietnamese Marital Satisfaction Scale $(M S S-V N)$ 
Linh Thi Trinh, Hanh Thi Phan
Berg, P., \& Snyder, D. K. (1983). Differential diagnosis of marital and sexual distress: A multidimensional approach. Journal of Sex and Marital Therapy, 7, 290295. http://dx.doi.org/10.1080/00926238108405430

Blood, R., \& Wolfe, D. (1960). Husbands and wives: The dynamics of married living. Glencoe, IL: Free Press.

Bowerman, C. (1957). Adjustment in marriage: Overall and in specific areas. Sociology and Social Research, 12, 257-263.

Bradbury, T. N., Fincham, F. D., \& Beach, S. R. H. (2000). Research on the nature and determinants of marital satisfaction: A decade in review. Journal of Marriage and Family, 62, 964-980. https://doi. org/10.1111/j.1741-3737.2000.00964.x.

Broman, C. L. (2005). Marital quality in black and white marriages. Journal of Family Issues, 26, 431441. https://doi.org/10.1177/0192513X04272439

Burr, W. (1967). Marital satisfaction: A concept reformation, theory and partial test of the theory. University of Minnesota. Ph.D. dissertation.

Burr, W. (1970). Satisfaction with various aspects of marriage over the life cycle: A random middle class sample. Journal of Marriage and the Family, 32, 29-37.

Busby, D. M., Crane, D. R., Larson, J. H., \& Christensen, C. (1995). A revision of the Dyadic Adjustment Scale for use with distressed and nondistressed couples: Construct hierarchy and multidimensional scale. Journal of Marital and Family Therapy, 21, 289-308. http://dx.doi.org/10.1111/j.1752-0606.1995. tb00163.x

Caughlin, J. P. (2002). The demand/withdraw pattern of communication as a predictor of marital satisfaction over time. Human Communication Research, 28, 49-85. https://doi.org/10.1111/j.1468-2958.2002. tb00798.x

Christensen, A., \& Shenk, J. L. (1991). Communication, conflict, and psychological distance in nondistressed, clinic, and divorcing couples. Journal of Consulting and Clinical Psychology, 59, 458-463. http://dx.doi.org/10.1037/0022-006X.59.3.458

Churchill, G. A. (1979). A paradigm for developing better measures of marketing constructs. Journal of Marketing Research, 16, 64-73. http://dx.doi. org/10.2307/3150876

Dalton, R. J., Pham, M. H., Pham, T. N, \& Ong, T. N. N. (2002). Social relations and social capital in Vietnam: Findings from the 2001 World Values Survey. Comparative Sociology, 1, 369-386. https://doi. org/10.1163/156913302100418646

Davison, S. L., Bell, R. J., LaChina, M., Holden, S. L., \& Davis, S. R. (2009). The relationship between self-reported sexual satisfaction and general well-being in women. The Journal of Sexual Medicine, 6, 2690-2697. https://doi.org/10.1111/j.17436109.2009.01406.x

Do, N. K., \& Weiss, B. (2017). Sự thay đổi mức độ hài lòng trong hai năm đầu hôn nhân [The change in satisfaction level in the first two years of marriage]. Proceeding of international conference The First Southeast Asia Regional Conference of Psychology: "Human well-being and sustainable development", 252-261.

Field, A. (2009). Discovering statistics using SPSS ( $3^{\text {rd }}$ ed.). London: Sage Publications Ltd.

Fowers, B. J. (1990). An interactional approach to standardized marital assessment: A literature review. Family Relations, 39, 368-377. https://doi. org/10.2307/585215.

Fun, J. L., \& Rogge, R. D. (2007). Testing the ruler with item response theory: Increasing precision of measurement for relationship satisfaction with the Couples Satisfaction Index. Journal of Family Psychology, 21, 572-583. https://doi.org/10.1037/08933200.21 .4 .572

Gager, C. T., \& Sanchez, L. (2003). Two as one? Couples' perceptions of time spent together, marital quality, and the risk of divorce. Journal of Family Issues, 24, 21-50. https://doi.org/10.1177/0192513X02238519

Graham, J. M., Liu, Y. J., \& Jeziorski, J. L. (2006). The Dyadic Adjustment Scale: A reliability generalization meta-analysis. Journal of Marriage and Family, 68, 701-717. https://doi.org/10.1111/j.17413737.2006.00284.x

Hendrick, S. (1988). Generic measure of relationship satisfaction. Journal of Marriage and the Family, 50, 93-98. http://dx.doi.org/10.2307/352430

Hicks, M., \& Platt, M. (1970). Marital happiness and stability: A review of the research in sixties. Journal of Marriage and the Family, 32, 553-574. http:// dx.doi.org/10.2307/350251

Hoang, B. T. (2012). Sự hài lòng về cuộc sống của người Việt Nam: Một số phát hiện ban đầu và hàm ý chính sách [Life satisfaction of Vietnamese people: Some initial findings and policy implications]. Tạp chí Nghiên cứu con người, 4, 3-13.

Holman, T. B., Busby, D. M., Doxey, C., Klein, D. M., \& Loyer-Carlson, V. (1997). The relationship evaluation (RELATE). Provo, UT: The RELATE Institute.

Honeycutt, J. (1986). A model of marital functioning based on an attraction paradigm and social-penetration dimensions. Journal of Marriage and the Family, 48, 651-659. http://dx.doi.org/10.2307/352051

Hunsley, J., Best, M., Lefebvre, M., \& Vito, D. (2001). The seven-item short form of the Dyadic Adjustment Scale: Further evidence of construct validity. American Journal of Family Therapy, 29, 325-335. https://doi.org/10.1080/01926180126501

Huppé, M., \& Cyr, M. (1997). Répartition des tâches familiales et satisfaction conjugale de couples à double revenu selon les cycles familiaux [Housework division and conjugal satisfaction of dualearner couples by family cycles]. Revue Canadienne de counseling et de thérapie, 31, 145-162.

Imamoglu, E. O., \& Yasak, Y. (1997). Dimensions of marital relationships as perceived by Turkish hus- 
bands and wives. Genetic Social \& General Psychology Monographs, 123, 211-232.

Inselberg, R. (1961). Social and psychological factors associated with high school marriages. Journal of Home Economics, 53, 766-772.

Jackson, J. B., Miller, R. B., Oka, M., \& Henry, R. G. (2014). Gender differences in marital satisfaction: A meta-analysis. Journal of Marriage and Family, 76, 105-129. https://doi.org/10.1111/jomf. 12077

Johnson, H. A., Zabriskie, R. B., \& Hill, B. (2006). The contribution of couple leisure involvement, leisure time, and leisure satisfaction to marital satisfaction. Marriage and Family Review, 40, 69-91. https://doi.org/10.1300/J002v40n01_05

Jose, O., \& Alfons, V. (2007). Do demographics affect marital satisfaction? Journal of Sex \& Marital Therapy, 33, 73-85. https://doi.org/10.1080/ 00926230600998573

Kurdek, L. A. (2005). Gender and marital satisfaction early in marriage: A growth curve approach. Journal of Marriage and Family, 67, 68-84. https://doi. org/10.1111/j.0022-2445.2005.00006.x

Lavner, J. A., Karney, B. R., \& Bradbury, T. N. (2016). Does couples' communication predict marital satisfaction, or does marital satisfaction predict communication? Journal of Marriage and Family, 78, 680-694. https://doi.org/10.1111/jomf.12301

Le, T. T. B. T. (2015). Phụ nữ trí thức và gia đình ngày nay [Female intellectuals and family today]. In T. V. T. Nguyen (Ed.), Female intellectual with the development career of the country (pp. 296-316). Hanoi: Nhà xuất bản Đại học Quốc gia Hà Nội.

Li, H., Zhang, J., Sin, L. T., \& Zhao, Y. (2006). Relative earnings of husbands and wives in urban China. China Economic Review, 17, 412-431. https://doi. org/10.1016/j.chieco.2005.11.001.

Locke, H. (1951). Predicting adjustment in marriage. New York: Henry Holt \& Co., Inc.

Locke, H., \& Wallace, K. (1959). Short marital adjustment and prediction tests: Their reliability and validity. Journal of Marriage and the Family, 21, 251-255. http://dx.doi.org/10.2307/348022

Lucas, T., Parkhill, M. R., Wendorf, C. A., Imamoglu, E. O., Weisfeld, C. C., Weisfeld, G. E., \& Shen, J. (2008). Cultural and evolutionary components of marital satisfaction: A multidimensional assessment of measurement invariance. Journal of Cross-Cultural Psychology, 39, 109-123. http:// dx.doi.org/10.1177/0022022107311969

MacEwen, K., \& Barling, J. (1993). Type A behavior and marital satisfaction: Differential effects of achievement striving and impatience/irritability. Journal of Marriage and Family, 55, 1001-1010. http://dx.doi.org/10.2307/352779

Manson, M. P., \& Lerner, A. (1970). The Marriage Adjustment Inventory: Manual. Los Angeles, CA: Western Psychological Services.
Markus, H. R., \& Kitayama, S. (1991). Culture and the self: Implications for cognition, emotion, and motivation. Psychological Review, 98, 224-253. http://dx.doi.org/10.1037/0033-295X.98.2.224

Myers, S. M., \& Booth, A. (1999). Marital strains and marital quality: The role of high and low focus of control. Journal of Marriage and the Family, 61, 423-436. https://doi.org/10.2307/353759.

Nguyen, H. D. (2015). Sự hài lòng với hôn nhân và các yếu tố tác động [Marital satisfaction and some impact factors]. Tạp chí Nghiên cứu Gia đình và Giới, 4, 3-14.

Nguyen, H. M. (2012). Các mối quan hệ trong gia đình ở Việt Nam: Một số vấn đề cần quan tâm [Family relationships in Vietnam: Some issues interests]. Tạp chí Xã hội học, 4, 91-100.

Nguyen, T. H. (2016). Sự hài lòng với cuộc sống gia đình của phụ nữ bị bạo lực gia đình [Satisfaction with the family life of women with domestic violence]. Tạp chí Tâm lý học, 8, 34-44.

Nye, F. (1988). Fifty years of family research, 19371987. Journal of Marriage and the Family, 50, 305316. https://doi.org/10.2307/351998

Olson, D. H., Druckman, J. M., \& Fournier, D. G. (1982). Prepare/Enrich: Counselor's Manual. Minneapolis, MN: Prepare-Enrich, Inc.

Pasch, L. A., \& Bradbury, T. N. (1998). Social support, conflict, and the development of marital dysfunction. Journal of Consulting and Clinical Psychology, 66, 219-230. http://dx.doi.org/10.1037/0022006X.66.2.219

Pimentel, E. E. (2006). Gender ideology, household behavior, and backlash in urban China. Journal of Family Issues, 27, 341-365. https://doi.org/10.1177/ $0192513 X 05283507$

Russell, R. J. H., \& Wells, P. A. (1993). Marriage and relationship questionnaire: MARQ handbook. Kent, UK: Hodder and Stoughton.

Santos-Iglesias, P., Vallejo-Medina, P., \& Sierra, J. C. (2009). Propiedades psicométricas de una versión breve de la escala de ajuste diádico en muestras españolas [Psychometric properties of a short version of the Dyadic Adjustment Scale in Spanish samples]. International Journal of Clinical and Health Psychology, 9, 501-517.

Schumm, W., Jurich, A., \& Bollman, S. (1981). The validity of Edmonds' Marital Conventional Scale. Journal of Psychology, 109, 65-71. https://doi.org/ 10.1080/00223980.1981.9915288

Snyder, D. K. (1979). Multidimensional assessment of marital satisfaction. Journal of Marriage and the Family, 41, 813-823. http://dx.doi.org/10.2307/ 351481

Snyder, D. K. (1983). Clinical and research applications of the Marital Satisfaction Inventory. In E. E. Filsinger (Ed.), Marriage and family assessment: A sourcebook for family therapy (pp. 169-190). Beverly Hills, CA: Sage Publications.
Preliminary development of the Vietnamese Marital Satisfaction Scale $(M S S-V N)$ 
Spanier, G. B. (1976). Measuring dyadic adjustment: New scales for assessing the quality of marriage and similar dyads. Journal of Marriage and the Family, 38, 15-28. http://dx.doi.org/10.2307/350547

Spanier, G. B., \& Lewis, R. (1980). Marital quality: A review of the seventies. Journal of Marriage and the Family, 42, 825-839. http://dx.doi.org/10.2307/ 351827

Stinnett, N., Collins, J., \& Montgomery, J. (1970). Marital need satisfaction of older husbands and

Linh Thi Trinh, Hanh Thi Phan wives. Journal of Marriage and the Family, 32, 428434. http://dx.doi.org/10.2307/350107

Tran, T. M. D., \& Nguyen, T. V. T. (2015). Nữ trí thức với công tác lãnh đạo quản lý [Intellectual female with leadership management]. Tạp chí Khoa học Đại học Quốc gia Hà Nội: Khoa học Xã hội và Nhân văn, 31, 1-12.

Turliuc, M. N., \& Muraru, A. A. (2013). Psychometric properties of the revised Dyadic Adjustment Scale on a sample of married adults. Journal of Psychological and Educational Research, 21, 49-76.

Vaughn, M. J., \& Baier, M. E. M. (1999). Reliability and validity of the Relationship Assessment Scale. American Journal of Family Therapy, 27, 137-147. http://dx.doi.org/10.1080/019261899262023

Vo, K. H. (2007). Vai trò giới và lượng hóa giá trị gia đình [Gender role and quantitative value of labor in the family]. Tạp chí Nghiên cứu Gia đình và Giới, 4, 81-86.

Volsky, J. A. (1998). Intimacy, marital satisfaction, and sexuality in mature couples. Concordia University. Ph.D. dissertation.

Wadsby, M. (1998). Evaluation of the Swedish version of the ENRICH Marital Inventory. Nordic Journal of Psychiatry, 52, 379-388. https://doi.org/10.1080/ 08039489850139409

Waite, L. J., \& Lillard, L. A. (1991). Children and marital disruption. American Journal of Sociology, 96, 930-953.

Ward, P. J., Lundberg, N. R., Zabriskie, R. B., \& Berrett, K. (2009). Measuring Marital Satisfaction: A Comparison of the Revised Dyadic Adjustment Scale and the Satisfaction with Married Life Scale. Marriage \& Family Review, 45, 412-429. https://doi. org/10.1080/01494920902828219

Whiteman, S. D., McHale, S. M., \& Crouter, A. C. (2007). Longitudinal changes in marital relationships: The role of offspring's pubertal development. Journal of Marriage and Family, 69(4), 1005-1020. https://doi.org/10.1111/j.1741-3737.2007.00427.x 